\title{
Supporting Learning During Short-Term Study Abroad: Evaluating a Pedagogical Intervention
}

\section{Kristen Sullivan}

Seinan Jo Gakuin University

\section{Reference Data}

Sullivan, K. (2021). Supporting learning during short-term study abroad: Evaluating a pedagogical intervention. In P. Clements, R. Derrah, \& P. Ferguson (Eds.), Communities of teachers \& learners. JALT. https://doi.org/10.37546/JALTPCP2020-21

This paper will discuss a pedagogical intervention that was implemented during a short-term study abroad program conducted in the summer of 2019 to Brisbane, Australia. The aim was study abroad program conducted in the summer of 2019 to Brisbane, Australia. The aim was
to create a deeper learning experience by encouraging participants to actively engage with their study abroad communities in the target language and to reflect on their experiences. The effectiveness of the intervention, titled the Challenges Project, is considered through an analysis of the reflection reports students wrote as part of the intervention, as well as responses to a postprogram feedback questionnaire. From this analysis the paper suggests that the effectiveness of the intervention could have been strengthened by providing more support of the reflection process before, during, and after the study abroad program. Specific recommendations for how this can be achieved are given.

本論文は、短期留学プログラムにおける学生の留学経験をより有意義なものにすることを目指して、2019年夏にオ一ストラ リア・ブリスベンでの短期留学期間中に実施した教育的介入について分析した。その教育的介入では、筆者が参加者に対し て、留学先のコミュニティと対象言語を使って積極的に関わることを目的としたアクティビティへの参加とその経験について振 り返ることを促した。ここでは、介入の一環として参加学生が留学中に書いた振り返りレポートの内容分析および帰国後に行 つたアンケート調査の分析結果から介入の効果を考察した。分析からは、留学開始前・留学中・留学後の各過程において、振り ったアンケート調査の分析結果から介入の効果を考察した。分析からは、留学開始前・留学中・留学後の各過程において、振り 教育的介入においては、学生の振り返り活動をどのようにして支えればよいかに関する具体的な方法を提示する。

tudy abroad is a rite of passage for many tertiary level students studying foreign languages. However, do the institutions and teachers involved in organizing such programs do enough to ensure students are getting the most out of their study abroad experiences? In this paper I consider the idea of pedagogical interventions in study abroad as a way to achieve this and evaluate one particular intervention, the Challenges Project, that was conducted during a short-term study abroad program. After explaining the concept of interventions in study abroad, I introduce the study abroad context of this study and the intervention. I then evaluate the intervention and conclude by offering ideas for how this and similar interventions can be designed to make them more effective.

\section{The Concept of Interventions in Study Abroad}

Until the recent outbreak of COVID-19, there had been a significant increase in international student mobility in the tertiary sector (Kuroda et al., 2018; Rumbley et al., 2012). In Japan, the number of university students participating in study abroad programs through partner agreements rose from 15,564 in 2003 to 66,450 in 2019, with an additional 40,896 students in 2019 participating in study abroad programs that did not involve a partner agreement (JASSO, 2021). Participation in short-term programs is noteworthy, with more than half of the 2019 participants taking part in a program of one month or less in duration (JASSO, 2021). Study abroad has become easier due to the increasing ease of international travel, as well as support from government, business, and academia, who identify study abroad experiences as a way to cultivate globally-minded graduates.

This increased interest in and support of study abroad is a welcome development. However, study abroad researchers from a variety of different perspectives have warned that simply participating in study abroad will not lead to the language, intercultural learning, and personal growth that is often anticipated. Researchers have argued that strategic pedagogical interventions are needed to equip study abroad students with the skills and mindsets they need and generally support them to get the most out of the study abroad experience (e.g., Jackson \& Oguro, 2018; Kappler Mikk et al., 2019; Kinginger, 2009; Plews \& Misfeldt, 2018; Vande Berg et al., 2012). 
Interventions can take many forms, but one important element is that they support students' critical reflection on experiential-based learning opportunities. Reflection is a skill that requires support and training. This can be achieved through in person or online mentoring (Giovanangeli et al., 2018; Jackson, 2018) and by providing specific instructions, prompts, and guided reflection questions. Indeed, as Pilon (2017, p. 144) stated, "[w]ithout strong prompts, these [reflections] can be no more than a laundry-list of what the students have done-a log of where they went, what they saw, and what they consumed-without analyzing what they have experienced."

In this paper I will report on an intervention undertaken during a short-term study abroad program to Australia offered as part of the foreign language program at a Japanese university. I have two aims in this paper. First, I will introduce the intervention and explain the ideas behind it. Second, I will evaluate the intervention and provide suggestions for how it and other similar interventions can be improved. I hope this discussion will provide ideas for fellow study abroad practitioners.

\section{The Study Abroad Context}

The context for the intervention was an optional five-week study abroad program held during the summer break of 2019 at a language school in Brisbane, Australia, with which the home institution has a partner agreement. At the home institution, which is a singlefaculty (economics) university located in Japan, short-term study abroad programs are offered annually to students, regardless of year and department, via an optional creditbased course. The course has been offered for more than 20 years, and the teacher in charge is decided on a rotating basis. Students successfully completing the course receive two general foreign language credits that can be used to meet graduation requirements. Seventeen students participated in the program in 2019; twelve second-year students (six female and six male) and five first-year students (three female and two male).

The students participated in a five-week long general English course and were allocated to different levels based on the results of a placement test taken on the first day. Classes were held between $8: 15$ to $10: 15$ and $10: 45$ to $12: 45$ Monday to Friday, with the afternoons and weekends free. The language school provided optional activities in the afternoons, as well as information about other free and charged activities. The students also participated in a paid buddy program in which they would meet several times with university students to talk, have lunch, and do other activities together in small groups throughout the program. Students stayed with individual homestay families, organized through the language school, who provided breakfast and dinner on weekdays and breakfast, lunch and dinner on weekends.
The students and I travelled to and from Brisbane as a group arriving one day before and departing one day after the start and finish of the language school program. The language school where they studied was affiliated with a university and located on the university campus, situated approximately 30 minutes from the city center by public transport. I was on campus every day to provide support as necessary and contacted the students daily with information and advice using a group social media account. I conducted pre- and post-program orientation sessions at the home institution, but did not teach any of the on-site classes.

\section{The Intervention}

Taking the literature on interventions in study abroad as a starting point, the project introduced in this paper aimed to challenge the participants to engage more deeply with their study abroad environment and community using the target language of English. The aims of the program were for students to: (1) try to improve their English skills, (2) think about intercultural understanding and intercultural communication, (3) learn about Australian culture and customs, and (4) become more proactive and independent. In order to help the students to achieve these goals, the intervention was designed to create opportunities for students to use English in real life situations, have intercultural experiences, participate in activities involving planning and moving outside of their comfort zones, and to reflect on these experiences. Named the Challenges Project, the intervention involved students completing at least ten challenges from a list of 40 during the study abroad program and reporting about what they had done in English on individual Google Classroom pages. The challenges included in-class and on-campus activities, off-campus travel and social interactions, engagement with cultural artefacts, consumer activities, and activities to learn about culture and society. Some examples were: inviting a classmate to lunch, visiting an outdoor market, visiting a museum or art gallery, ordering a coffee from a café, and asking someone what is currently popular in Australia. The full list of challenges is presented in Appendix A. The project explanation given to the students via Google Classroom and the group's social media account is presented in Appendix B. I responded to student reports with comments and questions made on Google Classroom during the study abroad period. Although strongly encouraged, participation in the Challenges Project was voluntary.

The challenges were not necessarily difficult but were specifically chosen to achieve three purposes. First, to create opportunities for interaction with as many people as possible. This included classmates, teachers and administration workers, students in the buddy program, homestay family members, people in consumer interactions, and 
strangers. Second, locations off campus were chosen for students to explore in order to create opportunities for them to plan and act independently. Third, direct interaction with cultural artefacts was included to provide chances to experience Australian culture and society. Furthermore, all of these activities promote communication during which communication breakdowns and intercultural mishaps could occur. Dealing with such situations would potentially become valuable learning experiences. Through the Challenges Project, I hoped students would see the different ways that they could learn and grow during their study abroad experience.

\section{Evaluation of the Intervention}

\section{Approach to Evaluation}

Through this evaluation I am not attempting to assess if the intervention led to quantifiably measurable gains in language proficiency or intercultural competence. The aim was to make initial observations about the potential effectiveness of the intervention through a qualitative analysis of the reflections that students wrote upon completing each challenge activity and their post-program feedback about the project. In the following sections, results from analysis of student reflection reports and the post-program feedback questionnaire will be introduced and discussed. Out of the 17 participants, ten wrote reflection reports on the Challenges Project. Twelve responded to the post-program feedback questionnaire, including seven students who had written reflection reports. Permission was received from participants to use their responses for research purposes.

\section{Analysis of Student Reflections}

First, I copied the students' reflection reports into Word. I then read them several times to find emerging patterns or trends in their structure and content with a particular focus on links to the intervention goals. In the process of coding the responses it became clear that the responses were generally brief and typically followed the pattern of giving a description of what was done followed by the student's impression of this. Moreover, many responses were akin to Pilon's (2017) "laundry-list" and did not go into enough detail to find connections to the intervention goals or evidence of confronting experiences or other learning. I believe this was due to a lack of guidance and support of the reflection element of the activity on my behalf, and I will present ideas for how to improve this aspect of the intervention in the final section of the paper.
The data were initially coded into six categories: (1) English-related, (2) links or comparisons to Japan, (3) new knowledge about Australian customs and people, (4) making connections with other countries, (5) gaining knowledge and meeting people through networks, and (6) making connections through Japan. Several sub-categories also emerged and were indexed, and the category labels were refined after further reflection and analysis. In the following sections I will introduce examples of student reflections related to three refined categories that are particularly connected to the course and intervention aims: (1) using English in interactions, (2) coming in touch with and evaluating different cultural practices, and (3) gaining new knowledge about the target community. These student reflections suggest that the intervention has the potential to work in the way envisioned. However, I believe that learning could have been further enhanced through the provision of more specific prompts and activities to guide the students' reflections, and I will provide ideas for this after introducing student responses for each category.

\section{Using English in Interactions}

When choosing the challenge activities it was anticipated that consumer encounters and travel would lead to chances of using English for various transactional purposes. Below are examples from four students reporting on using English in such interactions. The reader should note that the reports below are in the students' own words, and grammar mistakes have not been corrected.

I bought a black skirt. I didn't know if I could use the fitting rooms, so I asked that to the shop assistant. That skirt is my favorite one. (Student 1 )

I bought a pair of shoes. Because my shoes were broken when I played soccer. It costs about \$175. I'm gonna use them carefully. And I talked with assistants about my foot size. (Student 2)

I had a morning tea in Merlo Coffee with my friend from Saudi Arabia. It was difficult for me to order the coffee, but it was very delicious. (Student 3)

Yesterday I went to DFO (an outlet store) by myself. I was about to get lost, but I asked someone, and they helped me. (Student 4 )

These reports show that students had chances to use English in real life situations. However, to gain more from these experiences these students could have been prompted to reflect on such things as the language that they used and specific difficulties faced 
during their transactions. They could have been encouraged to engage in similar experiences again to experiment with language use and aim to achieve the transactions more smoothly. They could also have been asked to reflect on how they felt about making these linguistic achievements, which could become a source of motivation to sustain future learning.

Coming in Touch with and Evaluating Different Cultural Practices

Interaction with the target community is necessary for students to encounter different cultural practices. In the reports below, two students reflect on and evaluate differences in audience participation styles between Australia and Japan.

I went to cinema and watched IT chapter 2 with my buddy. Although I haven't watched chapter 1, I could enjoy it. My buddy screamed many times during the movie. So this sight was so interesting for me. (Student 5 )

I saw the Lion King with my classmates. I was surprised that people in Australia was chatting and singing during the movies. I like this custom because it is too tiring to put up to be quiet and stop during the movies in Japan. (Student 1)

When I added going to watch a movie to the challenge list, I did not envision that it would provide opportunities for students to encounter such cultural differences. This demonstrates how learning opportunities can exist in a myriad of contexts, and thus why encouragement of engagement with the target community in a variety of contexts is a crucial first step in study abroad programs. The positive evaluations of this cultural difference are noteworthy, however there could have been ways for this experience to be further utilized. For example, students could have been encouraged to think more about why these differences exist and to search for other differences in communication and interaction styles in different settings. Casual interviews with homestay families, buddies and classmates about any differences found could also have been conducted. Such interviews would be useful opportunities to confirm if experienced cultural practices are general to the target community at large or specific to certain subcultures or contexts.

\section{Gaining New Knowledge About the Target Community}

In the following reports, through communication with their homestay family and a visit to an art museum with their teacher, three students reflect on learning about two important aspects of Australian society: Aboriginal Australians and refugees. The fact this learning was supported by homestay families and teachers is important to note as it shows how interaction with people in the study abroad community can support student learning.

I asked my host family about Aussie singers. She introduced to me an Aboriginal singer. I thought he has a beautiful voice, but I can't understand his language. I was surprised that they use different language. (Student 3 )

My host family has aboriginal weapons. These look cool. And I held them. This experience was valuable. Once upon a time Aboriginal people used them to hunt. For instance, they were hunting animals and fishes. My host father taught me. (Student 2)

I went to an art museum in (the university) with my teacher after classes. What most impressed me was the short movie in a box. It was about refugees in Australia. Because I didn't know that there is such people in Australia, I can remember that strongly. (Student 1)

Learning about Australian society was a course aim thus it was encouraging to see students show interest in these topics. At the same time, these are complicated topics, and a deeper understanding of them would enable students to develop greater awareness of Australian society and history. Moreover, information obtained from certain sources could be biased or inaccurate and thus follow up from the teacher with information from other sources is important. Students could have been encouraged to read newspaper articles chosen by the teacher to take their interest and knowledge of these topics one step further.

\section{Post-Program Feedback Questionnaire}

Approximately three months after the study abroad program, participants were asked to complete a questionnaire. I wanted to gather feedback on the study abroad program in general, the Challenges Project, what they felt they had learned or gained through participation in the study abroad program, and what they regretted. There were also questions about their post study abroad activities, and future plans regarding language learning, intercultural exchange, and study abroad. Due to space limitations, only responses about the Challenges Project will be discussed here.

Regarding their thoughts about the project, students who wrote reflection reports evaluated it positively giving responses such as it pushed them to be active, to act consciously, to have goals, to try things that they would not necessarily have tried otherwise, and to use English in their new environment. There were also comments that 
it kept them from being bored and wasting time, acted as a guideline for how to spend their time, and provided chances to write in English. The students who did not write reflection reports responded that they had engaged in the activities but did not have enough time or were too tired to write a report.

In regard to encouraging students to try to be active during their study abroad, it seems that the Challenges Project may have been useful for the students. However, as suggested above, changes are necessary to support learner engagement with the reflection element of the activity.

\section{Ideas for Better Supporting Reflection in Study Abroad Interventions}

The lack of detail given in many of the reflection reports suggests that in setting up the project I placed too much emphasis on supporting student experiences and not enough effort in supporting student reflection. In this section I consider some initial ideas for how reflection could be better supported for the purposes of the Challenges Project which can also be used in other similar study abroad interventions. I also highlight some remaining issues.

As the literature states, the most effective intervention programs intervene before, during, and after study abroad programs (Jackson \& Oguro, 2018; Vande Berg et al., 2012). Although the Challenges Project was conducted during the actual period of the study abroad, activities that support reflection and the development of reflection skills should also have been conducted before departure and after return. However, it should be noted that there are barriers to achieving this. Firstly, it can be difficult to get students to participate in pre- and post-study abroad sessions if they are not receiving credit and have conflicting timetables (Pilon, 2017). Turning pre- and post-study abroad learning into another credit-bearing course that students must take could be one way to deal with this. Participation in the Challenges Project was voluntary. However, making the project a formally assessed piece of work that involves submissions before and after the study abroad could be another way to overcome this issue. In addition, in many cases teachers running study abroad programs are busy with administrative and technical issues particularly pre-departure, which makes it difficult for them to secure time to focus on pedagogical activities (Pilon, 2017). If these matters could be handled by administrative staff or partially outsourced to travel agencies, teachers could possibly gain more time to work with students on necessary pedagogical training.

\section{Pre-Departure}

First, after explanation of the project and its aims and procedures is provided, training in how to conduct reflection should be undertaken. Teachers need to provide clear and detailed instructions and prompts about what to reflect on, including guided reflection questions. Students should be instructed to focus on confronting situations or feelings in their reflections (Perry et al., 2012) and providing pre-departure instruction on key issues in intercultural understanding and communication could be useful here. The provision of reflection exemplars may also be helpful.

There is the possibility that students might question the need to engage in reflection, especially if they have expectations that their study abroad will only involve immersion in the host community or will just be an extended holiday. It is true that students pay a lot of money to participate in these programs and that they should not be expected to be engaged in academic study the whole time. However, they need to understand what is necessary to get the most out of their study abroad, and thus the rationale for the intervention, and this is especially true if their study abroad is linked to a credit-bearing course. Thus, it is important to clearly explain the purpose of the activities we are asking students to engage in from the outset.

At all stages, teachers should also consider what language to use when conducting reflection-related instruction, as well as what language to have students write their reflections in. In the Challenges Project, students were instructed to write their reflections in English, however the use of Japanese might have enabled them to engage in deeper reflections. Moreover, in many cases students may be writing their reflections at night after a long day of classes and various activities. Being flexible with language choice may support student engagement with reflection.

\section{During Study Abroad}

During the study abroad program, reflection should ideally be conducted as part of a dialogue between the teacher, and perhaps other students. This dialogue encourages students to think, elaborate, and challenge their ideas. It can also push students to investigate issues raised in their reflections. Many researchers have argued that cultural mentors or facilitators should be working with students in person or online during study abroad to support student reflection and learning (e.g., Giovanangeli et al., 2018; Jackson, 2018). During this study abroad program, I tried to create such a dialogue by responding to student reflection reports via Google Classroom, however this did not really result in a meaningful exchange. If a dialogue is to be a key element of the activity, 
it needs to be embedded within the activity with students knowing that engagement in the dialogue is just as important as their individual reflections. Moreover, the teacher conducting the mentoring needs to have the skills and knowledge to do this effectively (Giovanangeli et al., 2018; Lou et al., 2012; Selby, 2008). Other practical issues include when the dialogue should be conducted, how much time should be allocated to it, and whether it is necessary for every reflection report. Another possibility is to incorporate the experiential learning cycle into the reflection process and encourage students to test out ideas or hypotheses formed through reflection on previous experiences (McKinnon, 2018; Passarelli \& Kolb, 2012; Pilon, 2017). Direct guidance by the teacher or cultural mentor would be necessary here.

\section{Post Study Abroad}

Writing a report is an activity that students are commonly required to do after returning from study abroad. Students could be asked to choose one of the issues they touched on in their reflection reports written during study abroad, and to further investigate or reflect upon this in a longer assignment on their return. These reports could be shared and discussed with their peers in a debriefing session. In the case of this project, in the post-program questionnaire students were asked to write in English or Japanese about what they felt they had learned or gained through participation in the study abroad program. Even in their short responses, many students described what they had learned about the English language, communication, diversity in Australian society, other countries, and themselves by referring to specific experiences during their study abroad. There is much potential for linking work done during study abroad with a poststudy abroad activity.

\section{Conclusion}

With the outbreak of COVID-19, the immediate future of study abroad, particularly short-term study abroad, is unclear. How universities will continue offering students opportunities to engage with experiential learning in general is also uncertain. However with some institutions moving their study abroad programs online, it seems that the need to carefully design international education programs remains as crucial as ever. Perhaps this pause in study abroad will give us the chance to reflect on our practices so that we are able to continue supporting our students' language, intercultural learning, and personal development regardless of the future of international education.

\section{Bio Data}

Kristen Sullivan joined Seinan Jo Gakuin University in April 2021 and was previously associate professor at Shimonoseki City University. She is interested in study abroad, student exchange between Australia and Japan, internationalization of regional universities, curriculum design, and the development of learner autonomy. <sullivan@ seinan-jo.ac.jp>

\section{References}

Giovanangeli, A., Oguro, S., \& Harbon, L. (2018). Mentoring students' intercultural learning during study abroad. In J. Jackson \& S. Oguro (Eds.), Intercultural interventions in study abroad (pp. 88 102). Routledge. https://doi.org/10.4324/9781315276595

Jackson, J. (2018). Optimizing intercultural learning and engagement abroad through online mentoring. In J. Jackson \& S. Oguro (Eds.), Intercultural interventions in study abroad (pp. 119136). Routledge. https://doi.org/10.4324/9781315276595

Jackson, J., \& Oguro, S. (Eds.). (2018). Intercultural interventions in study abroad. Routledge. https:// doi.org/10.4324/9781315276595

JASSO (Japan Student Services Organization). (2021). 2019 (reiwa gan) nendo nihonjin gakusei ryugaku jyokyo chosa kekka. [Results of the investigation of Japanese students' study abroad in the academic year of 2019]. Retrieved from https://www.studyinjapan.go.jp/ja/_mt/2021/03/ date2019n.pdf

Kappler Mikk, B., Cohen, A. D., \& Paige, R. M. (2019). Maximizing study abroad: An instructional guide to strategies for language and culture learning and use. Center for Advanced Research on Language Acquisition University of Minnesota.

Kinginger, C. (2009). Contemporary study abroad and foreign language learning: An activists guidebook for language educators. CALPER Publications.

Kuroda, K., Sugimura, M., Kitamura, Y., \& Asada, S. (2018). Internationalization of higher education and student mobility in Japan and Asia. (Paper commissioned for the 2019 Global Education Monitoring Report, Migration, displacement and education: Building bridges, not walls). UNESCO. Retrieved from https://www.jica.go.jp/jica-ri/ja/publication/other/ 175nbg0000108nmr-att/Background_Kuroda.pdf

Lou, K. H., Vande Berg, M., \& Paige, M. (2012). Intervening in student learning abroad: Closing insights. In M. Vande Berg, R. M. Paige, \& K. H. Lou (Eds.), Student learning abroad: What our students are learning, what they're not, and what we can do about it (pp. 411-419). Stylus.

McKinnon, S. (2018). Foregrounding intercultural learning during study abroad as part of a modern languages degree. In J. Jackson \& S. Oguro (Eds.), Intercultural interventions in study abroad (pp. 103-118). Routledge. https://doi.org/10.4324/9781315276595 


\section{JALT2020}

COMMUNITIES OF

Passarelli, A., \& Kolb, D. (2012). Using experiential learning theory to promote student learning and development in programs of education abroad. In M. Vande Berg, R. M. Paige \& K. H. Lou (Eds.), Student learning abroad: What our students are learning, what they're not, and what we can do about it (pp. 137-161). Stylus.

Perry, L., Stoner, L., \& Tarrant, M. (2012). More than a vacation: Short-term study abroad as a critically reflective, transformative learning experience. Creative Education, 3(5), 679-683. doi: 10.4236/ce.2012.35101

Pilon, S. (2017). Developing intercultural learning among students in short-term study abroad programs. NECTFL Review-Special Issue, 79, 133-153. Retrieved from https://www.nectfl.org/ wp-content/uploads/2017/02/NECTFL-SPECIAL-ISSUE.pdf

Plews, J. L. \& Misfeldt, K. (2018). Introduction: Shifting attention to second language study abroad programming, pedagogy, and participant engagement. In J. L. Plews \& K. Misfeldt (Eds.), Second language study abroad: Programming, pedagogy, and participant engagement (pp. 1-21). Palgrave Macmillan. https://doi.org/10.1007/978-3-319-77134-2_1

Rumbley, L. E., Altbach, P. G. \& Reisberg, L. (2012). Internationalization within the higher education context. In D. K. Deardoff, H. de Wit, J. D. Heyl \& T. Adams (Eds.), The SAGE handbook of international higher education (pp. 3-26). SAGE. http://dx.doi.org/10.4135/9781452218397

Selby, R. (2008). Designing transformation in international education. In V. Savicki (Ed.), Developing intercultural competence and transformation: Theory, research, and application in international education (pp. 1-10). Stylus.

Vande Berg, M., Paige, R. M., \& Lou, K. H. (Eds.). (2012). Student learning abroad: What our students are learning, what they're not, and what we can do about it. Stylus.

\section{Appendix A}

The Challenge Activities

1. Start a conversation with a student at the language school who you don't know.

2. Invite one of your language school (non-Japanese) classmates to lunch or morning tea.

3. Talk with your language school English teacher during break time.

4. Put up your hand and ask or answer a question during class.

5. Ask the people at the Level 4 reception desk a question.

6. Play some sports at the language school or university.

7. Participate in an afternoon activity offered by the language school.
8. Participate in an afternoon workshop offered by the language school.

9. Schedule an "Individual Consultation" and meet with a Learning Advisor for personalized help with your English

10. Participate in a university Japanese Society meeting (Wednesdays and Thursdays).

11. Borrow a book from the language school or university library and try to read it.

12. Explore the university and find something interesting.

(1-12 are activities that could be conducted at the language school or university campus and encouraged interaction with people on campus.)

13. Ride the city cat (a ferry) from the university to the city.

14. Ride public transport by yourself.

15. Travel somewhere by yourself.

16. Go to a tourist attraction with your friends.

17. Go to the beach.

18. Go to a zoo and see some Australian animals.

19. Visit an outdoors market and talk with a shop keeper.

20. Explore Brisbane city and find something interesting.

(13-20 are activities that encouraged students to move away from the campus and engage in consumer interactions.)

21. Buy and read a newspaper.

22. Buy and read a magazine.

23. Buy and read a book.

24. Watch the news on TV.

25. Visit a museum or art gallery.

26. Go and see a movie.

27. Go and see a play, musical or concert.

(21-27 are activities that encouraged students to come in touch with cultural artefacts and learn about Australian society.) 


\section{JALT2020}

COMMUNITIES OF
TEACHERS \& IEARNERS

\section{Go to a pub or bar.}

29. Order a coffee from a café.

30. Buy a $\$ 1$ scratchie (a scratch card instant lottery ticket) (but only one time).

31. Buy some clothes and talk with the shop assistant.

32. Find some interesting food at a supermarket.

(28-32 are activities that encourage students to engage in consumer interactions.)

33. Teach your host family a Japanese dish.

34. Get your host family to teach you a dish.

35. Eat some new food (ethnic food or traditional Australian food).

36. Ask someone about what is popular in Australia now.

37. Use an Aussie proverb or slang expression in your conversation.

38. Learn something about Indigenous Australians.

39. Find some information about the Queensland or Australian economy, or about Australia-Japan relations.

40. Find somewhere in Australia where you want to visit next time.

41. Or your original ideas! If you challenged yourself to do something unique, tell me about it!

(33-40 are other activities encouraging students to learn about culture and society, potentially through interaction with others. Students were also given the option to create their own challenge activity.)

\section{Appendix B}

Explanation of the Challenges Project

- Your mission during this study abroad program is to experience many things and to reflect on your experiences. Through this I want you to become conscious of cultural and social differences, to grow as a person, to improve your English, and of course to have fun!

- Your mission is to complete at least 10 "challenges" from this list. You can do the same challenge more than once, of course. But trying a variety would be more fun. Also, you can come up with your own challenge too.
- After you have completed the challenge, please write a brief summary/reflection as a post on Google Classroom. Please also attach a photo as evidence. So, how many challenges can you complete? 